Eur J Clin Chem Clin Biochem

1995; 33:231-238

(c) 1995 Walter de Gruyter \& Co.

Berlin · New York

\title{
Storage of Serum or Whole Blood Samples? Effects of Time and Temperature on 22 Serum Analytes
}

\author{
By Michael Heins ${ }^{1}$, Wolfgang Heil ${ }^{2}$ and Wolfgang Withold ${ }^{1}$ \\ ${ }^{1}$ Institut für Klinische Chemie und Laboratoriumsdiagnostik der Heinrich-Heine-Universität Dïsseldorf, Germany \\ 2 Zentrallaboratorium Klinikum Wuppertal-Barmen, Universität Witten/Herdecke, Germany
}

(Received July 7, 1994/January 9, 1995)

Summary: Information on the stability of serum analytes during storage of serum or whole blood samples is often incomplete and sometimes contradictory. Using a widely available analyser (Hitachi 737/Boehringer), we therefore determined the effects of storage time and temperature on the measured concentrations of the following serum analytes: sodium, potassium, calcium, chloride, inorganic phosphate, magnesium, creatinine, urea, uric acid, bilirubin, cholesterol, HDL- and LDL-cholesterol, triacylglycerols, creatine kinase, aspartate aminotransferase, alanine aminotransferase, $\gamma$-glutamyltransferase, alkaline phosphatase, $\alpha$-amylase, lactate dehydrogenase and cholinesterase.

When separated serum was stored at $+9{ }^{\circ} \mathrm{C}$ for seven days, the mean changes in inorganic phosphate and lactate dehydrogenase exceeded significantly ( $p<0.05$ or 0.001 , respectively) the maximum allowable inaccuracy according to the Guidelines of the German Federal Medical Council; all other quantities were sufficiently stable.

In serum at room temperature, inorganic phosphate, uric acid, HDL-cholesterol and triacylglycerols increased continuously, whereas bilirubin, LDL-cholesterol, creatine kinase and aspartate aminotransferase decreased more than the guidelines permit during the storage period $(p<0.05$ for aspartate aminotransferase, $p<0.001$ for the other analytes mentioned).

In whole blood stored for 7 days at $+9^{\circ} \mathrm{C}$, only the following serum analytes satisfied the stability requirements of the guidelines: calcium, urea, cholesterol, HDL-cholesterol, LDL-cholesterol, triacylglycerols, creatine kinase, $\gamma$-glutamyltransferase and cholinesterase. When stored at room temperature, only sodium, uric acid, bilirubin, cholesterol, triacylglycerols, aspartate aminotransferase, alanine aminotransferase, alkaline phosphatase, $\alpha$-amylase and cholinesterase were still stable after 3 days.

The data collected show that all quantities examined are sufficiently stable for four days in separated serum stored at $+9{ }^{\circ} \mathrm{C}$.

\section{Introduction}

A general problem in clinical laboratories is the stability of analytes during sample storage. Analytical methods have been continuously optimised to minimise the influence of disturbing factors. In earlier studies, information on the stability of analytes in serum and whole blood was based on methods, which have since become obsolete $(1-5)$. In addition, the extent of interference by hae- molysis strongly depends on the methods employed and the various modifications of a given method. Therefore we determined the effects of storage time and temperature on the measurement of the following serum analytes: sodium, potassium, calcium, chloride, inorganic phosphate, magnesium, creatinine, urea, uric acid, bilirubin, cholesterol, HDL-cholesterol, LDL-cholesterol, triacylglycerols, creatine kinase (EC 2.7.3.2), aspartate aminotransferase (EC 2.6.1.1), alanine aminotransferase (EC 2.6.1.2), $\gamma$-glutamyltransferase (EC 2.3.2.2), alka- 
line phosphatase (EC 3.1.3.1), ${ }^{-} \alpha$-amylase (EC 3.2.1.1), lactate dehydrogenase (EC 1.1.1.27) and cholinesterase (EC 3.1.1.8).

\section{Materials and Methods}

\section{Apparatus}

HDL- and LDL-cholesterol were determined manually using a spectral line photometer 6118 (Eppendorf). Magnesium was determined with an Hitachi 704 analyser (Boehringer) with batchwise processing of samples, while the other quantities were determined in random access made with an Hitachi 737 analyser (Boehringer). A spectrophotometer Lambda 5 (Perkin Elmer) was used for the spectrophotometric determination of free haemoglobin.

\section{Reagents}

The reagents and methods used are shown in table 1. Free haemoglobin in serum was determined spectrophotometrically according to Harboe (6).

\section{Samples}

Venous blood samples $(210 \mathrm{ml})$ were drawn at 8.00 a.m. from 20 fasting, apparently healthy subjects in sitting position. For this purpose, $10 \mathrm{ml}$ Vacutainer ${ }^{\circledR}$ sample tubes with polyester separation gel were used. These blood specimens were then randomised. Eleven of the blood samples were centrifuged immediately for 10 minutes at $3400 \mathrm{~g}$ and one of the sera obtained was used for measurement of the aforementioned quantities. Five serum tubes and 5 whole blood tubes were stored at room temperature (at $23-27^{\circ} \mathrm{C}$ in a dark cupboard) and the remaining 5 of each, at $9^{\circ} \mathrm{C}$ in a dark refrigerator. Centrifugation of the whole blood samples was

Tab. 1 Reagents and methods used in this study

\begin{tabular}{|c|c|c|c|c|c|}
\hline Analyte & Method & $\begin{array}{l}\text { Catalogue } \\
\text { Number } \\
\text { (Reagent } 1 \text { and 2) }\end{array}$ & $\begin{array}{l}\text { Inter- } \\
\text { assay- } \\
\text { impre- } \\
\text { cision } \\
(\%)\end{array}$ & $\begin{array}{l}\text { Maximum } \\
\text { allowable } \\
\text { inaccu- } \\
\text { racy } \\
(\%)\end{array}$ & $\begin{array}{l}\text { Day zero } \\
(100 \% \text { value } \\
\text { of figures } 2-5)\end{array}$ \\
\hline Sodium & $\begin{array}{l}\text { Indirect potentiometry (Boehringer Mann- } \\
\text { heim GmbH, Mannheim, Germany) }\end{array}$ & $*$ & 0.7 & 2.0 & $139.0 \mathrm{mmol} / \mathrm{l}$ \\
\hline Potassium & Indirect potentiometry (Boehringer) & * & 1.3 & 2.7 & $3.92 \mathrm{mmol} / 1$ \\
\hline Calcium & $\begin{array}{l}o \text {-Cresolphthalein complexone (Boeh- } \\
\text { ringer) }\end{array}$ & 1127551 and 1127650 & 1.4 & 3.3 & $2.28 \mathrm{mmol} / 1$ \\
\hline Chloride & Indirect potentiometry (Boehringer) & * & 1.3 & 2.0 & $106.6 \mathrm{mmol} / \mathrm{l}$ \\
\hline $\begin{array}{l}\text { Inorganic } \\
\text { phosphate }\end{array}$ & Ammonium molybdate (Boehringer) & 836281 & 2.0 & 5.0 & $1.33 \mathrm{mmol} / 1$ \\
\hline Magnesium & $\begin{array}{l}\text { Calmagite (Sigma Chemical Co., St. Louis } \\
\text { [U.S.A.]) }\end{array}$ & $595-\mathrm{A}$ & 3.7 & 4.0 & $0.79 \mathrm{mmol} / 1$ \\
\hline Creatinine & $\begin{array}{l}\text { Kinetic modification of the Jaffé method } \\
\text { (Boehringer) }\end{array}$ & 1127918 and 1127926 & 3.1 & 6.0 & $91.1 \mu \mathrm{mol} / \mathrm{l}$ \\
\hline Urea & Enzymatic kinetic UV test (Boehringer) & 1127918 and 1127926 & 1.6 & 8.0 & $5.12 \mathrm{mmol} / \mathrm{l}$ \\
\hline Uric acid & $\begin{array}{l}\text { Enzymatic colorimetric test (Peridoch- } \\
\text { rom }^{\odot} \text { ) (Boehringer) }\end{array}$ & 791679 and 120927 & 2.5 & 6.0 & $281.1 \mu \mathrm{mol} / 1$ \\
\hline Bilirubin & $\begin{array}{l}\text { Dichlorphenyl diazonium method (Boeh- } \\
\text { ringer) }\end{array}$ & 1127535 and 1127543 & 3.5 & 7.0 & $9.49 \mu \mathrm{mol} / 1$ \\
\hline Cholesterol, total & $\begin{array}{l}\text { Enzymatic colorimetric test (CHOD-PAP } \\
\text { method) (E. Merck, Darmstadt, Germany) }\end{array}$ & $\begin{array}{l}14164,14165,14166 \\
\text { and } 14167\end{array}$ & 1.8 & 6.0 & $5.05 \mathrm{mmol} / \mathrm{l}$ \\
\hline HDL-cholesterol & $\begin{array}{l}\text { Precipitation with phosphotungstic acid/ } \\
\mathrm{MgCl}_{2} \text { (Merck) }\end{array}$ & $14210,14164-67$ & 3.0 & {$[6.0]$} & $1.52 \mathrm{mmol} / 1$ \\
\hline LDL-cholesterol & $\begin{array}{l}\text { Precipitation with heparin at } \mathrm{pH} 5.12 \\
\text { (Merck) }\end{array}$ & $14992,14164-67$ & 4.7 & {$[6.0]$} & $3.10 \mathrm{mmol} / \mathrm{l}$ \\
\hline Triacylglycerol & $\begin{array}{l}\text { Enzymatic colorimetric test (GPO-PAP } \\
\text { method) (Boehringer) }\end{array}$ & 1128027 and 1201301 & 2.0 & 7.0 & $1.25 \mathrm{mmol} / \mathrm{I}$ \\
\hline Creatine kinase & $\begin{array}{l}\text { Optimised standard method }{ }^{* *} \text { at }+25^{\circ} \mathrm{C} \\
\text { (Boehringer) }\end{array}$ & 1127586 and 1091077 & 1.6 & 8.0 & $43.3 \mathrm{U} / 1$ \\
\hline $\begin{array}{l}\text { Aspartate } \\
\text { aminotransferase }\end{array}$ & $\begin{array}{l}\text { Optimised standard method** at }+25^{\circ} \mathrm{C} \\
\text { (Boehringer) }\end{array}$ & 1127802 and 1127829 & 2.4 & 7.0 & $9.10 \mathrm{U} / 1$ \\
\hline $\begin{array}{l}\text { Alanine } \\
\text { aminotransferase }\end{array}$ & $\begin{array}{l}\text { Optimised standard method** at }+25^{\circ} \mathrm{C} \\
\text { (Boehringer) }\end{array}$ & 1127837 and 1127845 & 1.8 & 7.0 & $7.68 \mathrm{U} / 1$ \\
\hline $\begin{array}{l}\gamma \text {-Glutamyl- } \\
\text { transferase }\end{array}$ & $\begin{array}{l}\text { According to Szász new at }+25^{\circ} \mathrm{C} \text { (Boeh- } \\
\text { ringer) }\end{array}$ & 1127853 and 1127861 & 2.6 & 7.0 & $9.80 \mathrm{U} / 1$ \\
\hline $\begin{array}{l}\text { Alkaline } \\
\text { phosphatase }\end{array}$ & $\begin{array}{l}\text { Optimised standard method** at }+25^{\circ} \mathrm{C} \\
\text { (Boehringer) }\end{array}$ & 1127454 and 791377 & 2.7 & 7.0 & $100.4 \mathrm{U} / \mathrm{l}$ \\
\hline$\alpha$-Amylase & PNP method at $+25^{\circ} \mathrm{C}$ (Boehringer) & 1209035 and 791393 & 1.1 & {$[7.0]$} & $72.5 \mathrm{U} / 1$ \\
\hline $\begin{array}{l}\text { Lactate } \\
\text { dehydrogenase }\end{array}$ & $\begin{array}{l}\text { Optimised standard method** at }+25^{\circ} \mathrm{C} \\
\text { (Boehringer) }\end{array}$ & 1127969 and 1127977 & 1.7 & 7.0 & $143.1 \mathrm{U} / 1$ \\
\hline Cholinesterase & $\begin{array}{l}\text { Butyrylthiocholine iodide at }+25^{\circ} \mathrm{C} \\
\text { (Boehringer) }\end{array}$ & 1127667 and 1127675 & 1.7 & 7.0 & $5082.2 \mathrm{U} / \mathrm{I}$ \\
\hline
\end{tabular}

* Ion-selective electrode of Hitachi 737

** according to the Recommendations of the German Society of Clinical Chemistry

For the numbers in brackets there are no limits defined. The limits were derived from other enzymes or lipoproteins. 
performed on the day of analysis. After 1, 2, 3, 4 and 7 days, measurements of the quantities examined were repeated. To avoid evaporation, sample tubes were kept closed until analysis.

\section{Statistical analysis}

The Friedman test was used to examine the influence of storage time on the measurable quantities. The changes of the values after storage were calculated for each subject as percentages of the initial values. The mean and standard deviation was computed and plotted. SPSS for windows was used to compute the Friedman test and Lotus $1-2-3$ for $O S / 2$ to calculate the percentage deviation.

\section{Results}

\section{Release of haemoglobin}

The release of free haemoglobin in whole blood samples of 10 apparently healthy persons stored at $9{ }^{\circ} \mathrm{C}$ in a refrigerator and at room temperature in a dark cupboard is shown in figure 1 .

\section{Storage of serum and whole blood}

Significant changes in mean concentration or mean catalytic concentration during storage, which exceeded the maximum inaccuracy allowed by the Guidelines of the German Federal Council (7), were shown by the following quantities:

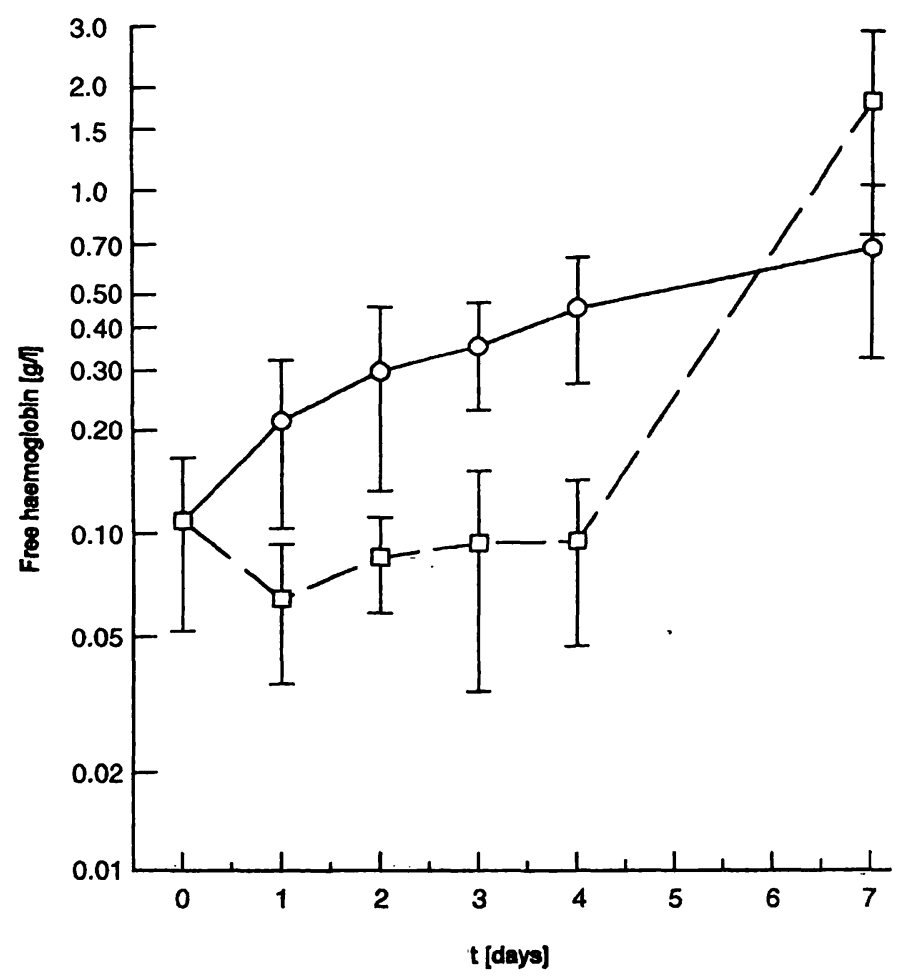

Fig. 1 Release of free haemoglobin during storage (circle at $9^{\circ} \mathrm{C}$, square at room temperature) in clotted blood $(n=10)$. Values are given in mean and standard deviation.
Analyte, condition Change, time

Serum at $9{ }^{\circ} \mathrm{C}$

Inorganic phosphate

Lactate dehydrogenase

(increase after 7 days)

(decrease after 7 days)

Serum at room temperature

Inorganic phosphate

Uric acid

Bilirubin

HDL-cholesterol

LDL-cholesterol

Triacylglycerols

Creatine kinase

Aspartate aminotransferase

(increase after 2 days)

(increase after 3 days)

(decrease after 3 days)

(increase after 3 days)

(decrease after 2 days)

(increase after 2 days)

(decrease after 3 days)

(decrease after 7 days)

Whole blood at $9^{\circ} \mathrm{C}$

Sodium

Potassium

Chloride

Inorganic phosphate

Magnesium

Creatinine

Uric acid

Alkaline phosphatase

$\alpha$-Amylase

Lactate dehydrogenase

(decrease after 1 day)

(increase after 1 day)

(decrease after 2 days)

(increase after 4 days)

(increase after 7 days)

(decrease after 1 day)

(increase after 3 days)

(decrease after 1 day)

(decrease after 2 days)

(increase after 1 day)

Whole blood at room temperature

Sodium

Potassium

(decrease after 7 days)

Calcium

(increase after 1 day)

(decrease after 3 days)

Chloride

Inorganic phosphate

Magnesium

Creatinine

Urea

HDL-cholesterol

LDL-cholesterol

Alanine aminotransferase

Alkaline phosphatase

$\alpha$-Amylase

Lactate dehydrogenase

(decrease after 1 day)

(increase after 1 day)

(increase after 1 day)

(increase after 2 days)

(increase after 2 days)

(increase after 3 days)

(decrease after 2 days)

(decrease after 7 days)

(decrease after 7 days)

(decrease after 7 days)

(increase after 1 day)

The changes in the measurable quantities are shown in percentage of the initial value in figures $2-5$.

\section{Discussion}

Several phenomena were observed during sample storage. In serum, some analytes showed a decrease, others an increase due to enzymatic cleavage of precursor molecules. Prolonged contact of serum with red cells resulted in an exchange of substances between serum and the erythrocytes, which can cause dilution or can 


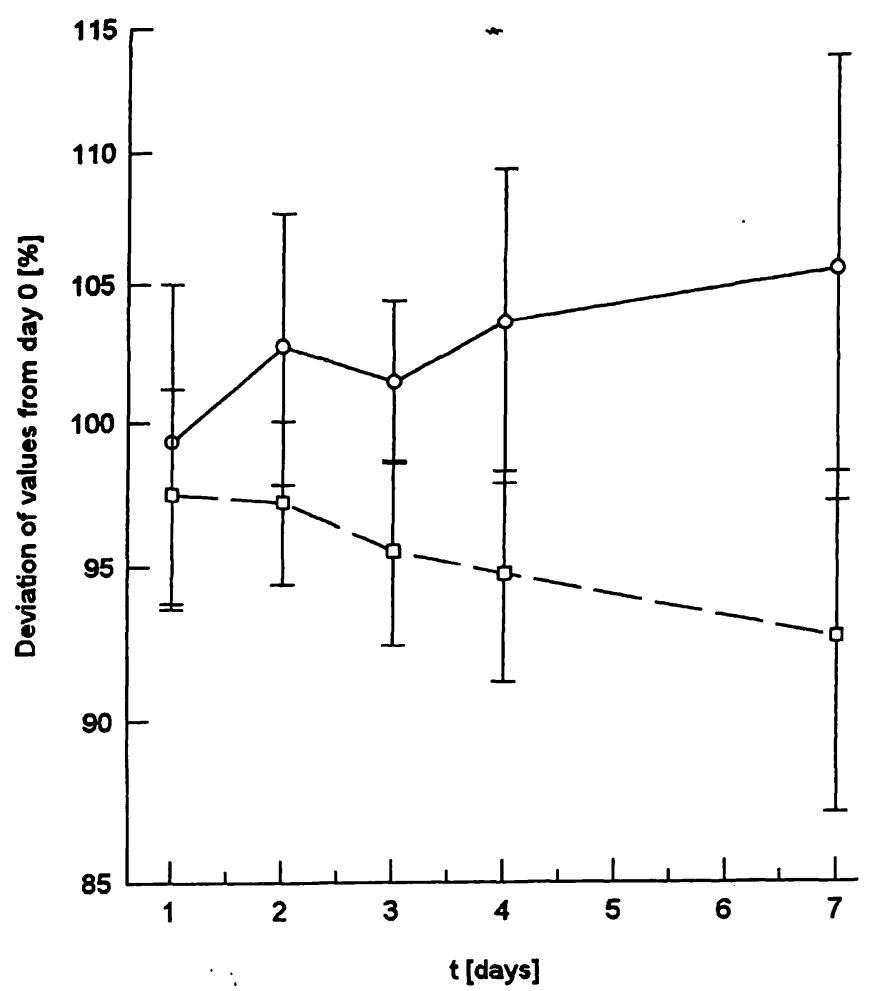

Fig. 2 Storage of centrifuged vacutainer ${ }^{\circledR}$ tubes at $9^{\circ} \mathrm{C}$. Deviation of the measurable quantities as mean and standard deviation in percentage of the initial value. From the top to the bottom: inorganic phosphate (circle) and lactate dehydrogenase (square).

lead to an increase of analyte concentrations in the serum. Haemolysis causes the release of erythrocytic constituents, which can result in increased values or in dilution leading to decreased values. Haemoglobin may also interfere in the measurement, e.g., in the photometric quantification of constituents. This influence also de-

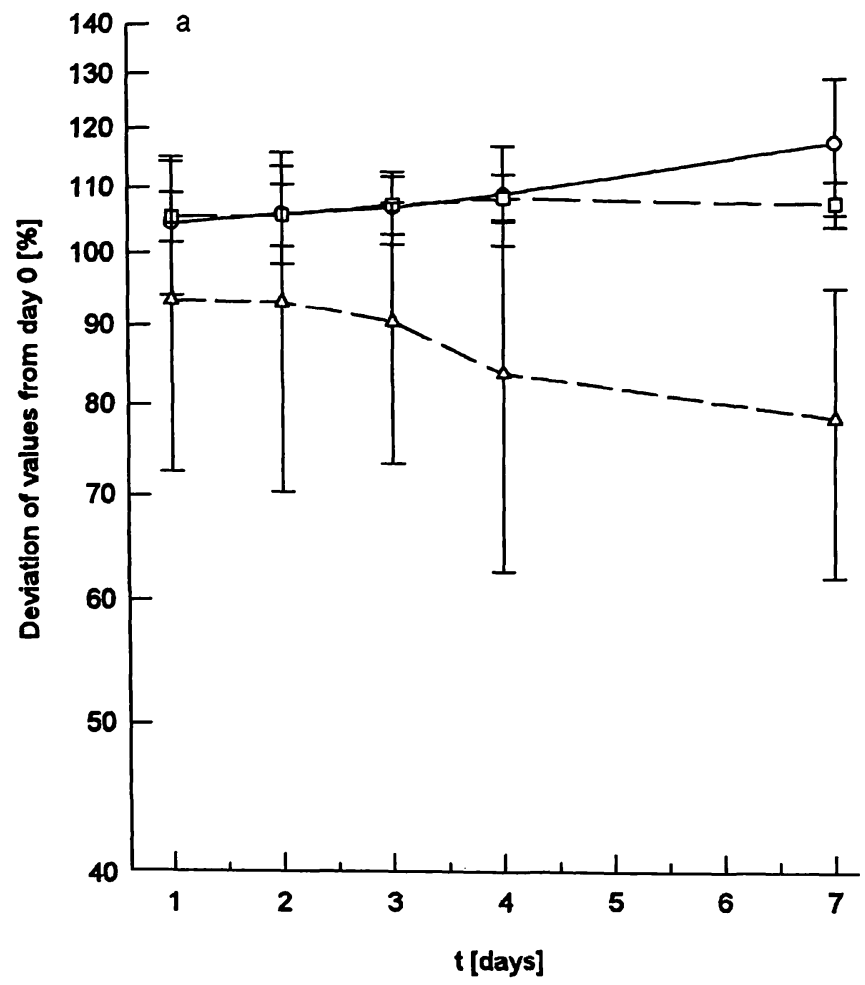

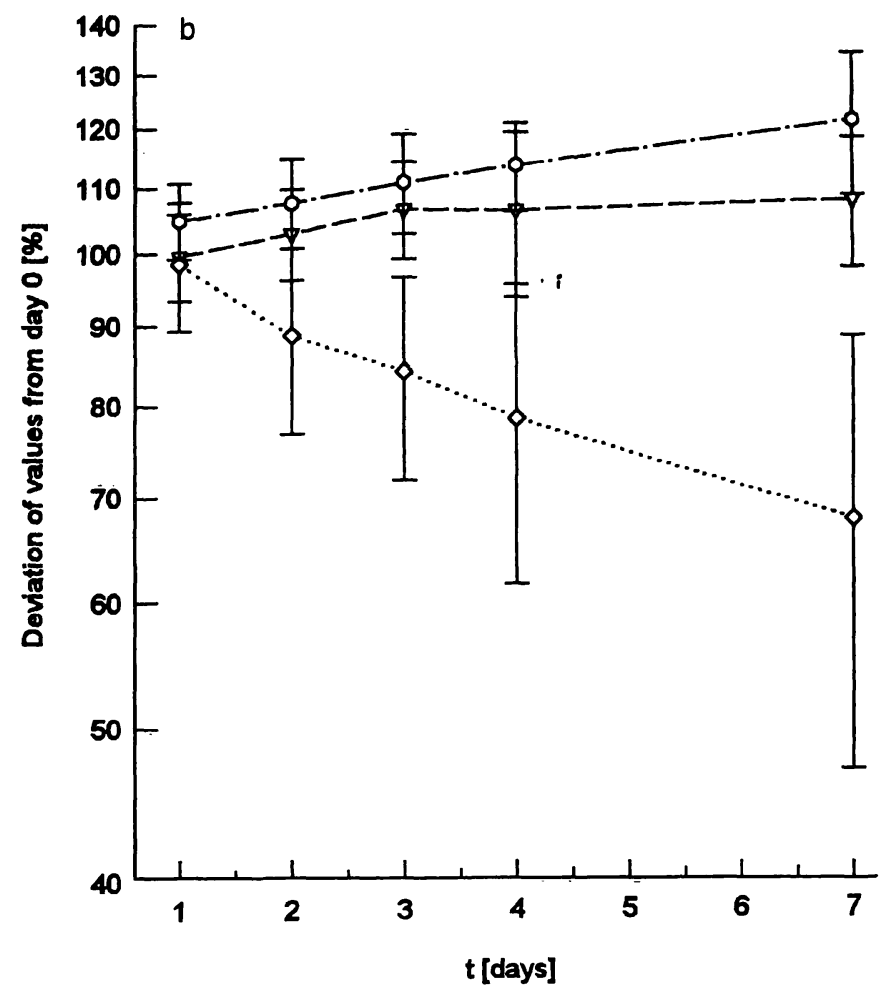

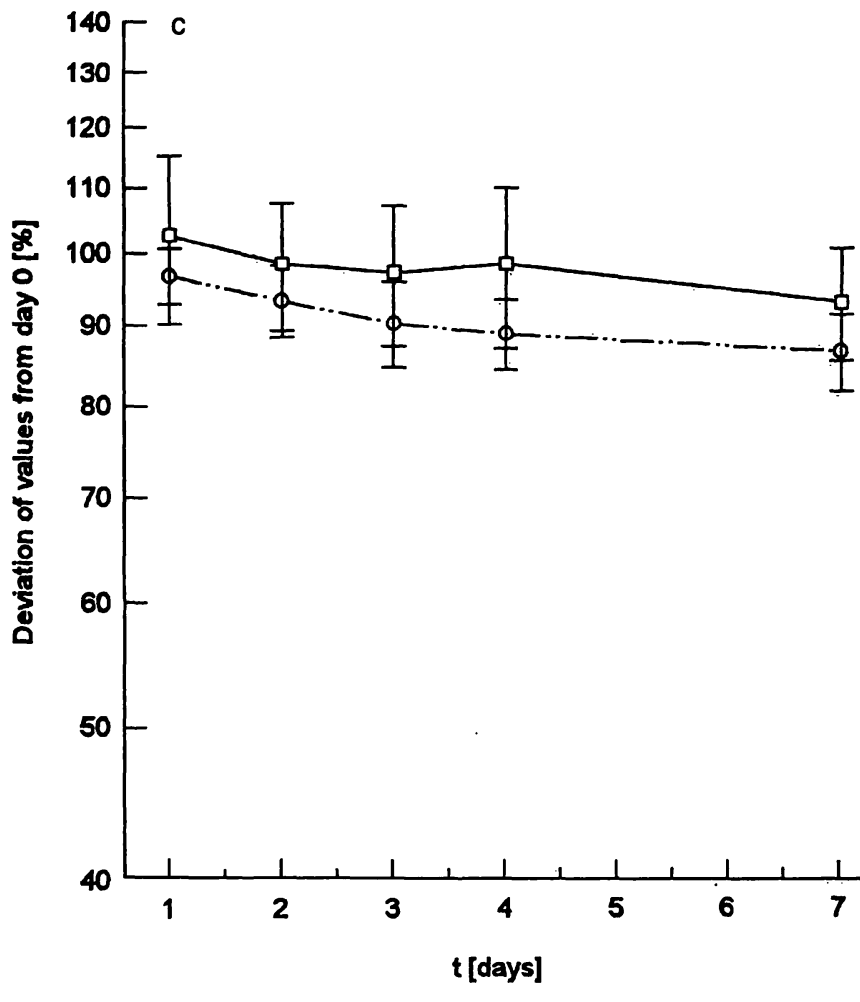

Fig. 3 Storage of centrifuged vacutainer ${ }^{\circledR}$ tubes at room temperature. Deviation of the measurable quantities as mean and standard deviation in percentage of the initial value.

a) Electrolytes, trace elements and metabolites from top to bottom: inorganic phosphate (circle), uric acid (square) and bilirubin (triangle).

b) Lipids and lipoproteins from top to bottom: triacylglycerols (hexagon), HDL-cholesterol (wedge) and LDL-cholesterol (rhomb).

c) Enzymes from top to bottom: aspartate aminotransferase (square) and creatine kinase (circle). 

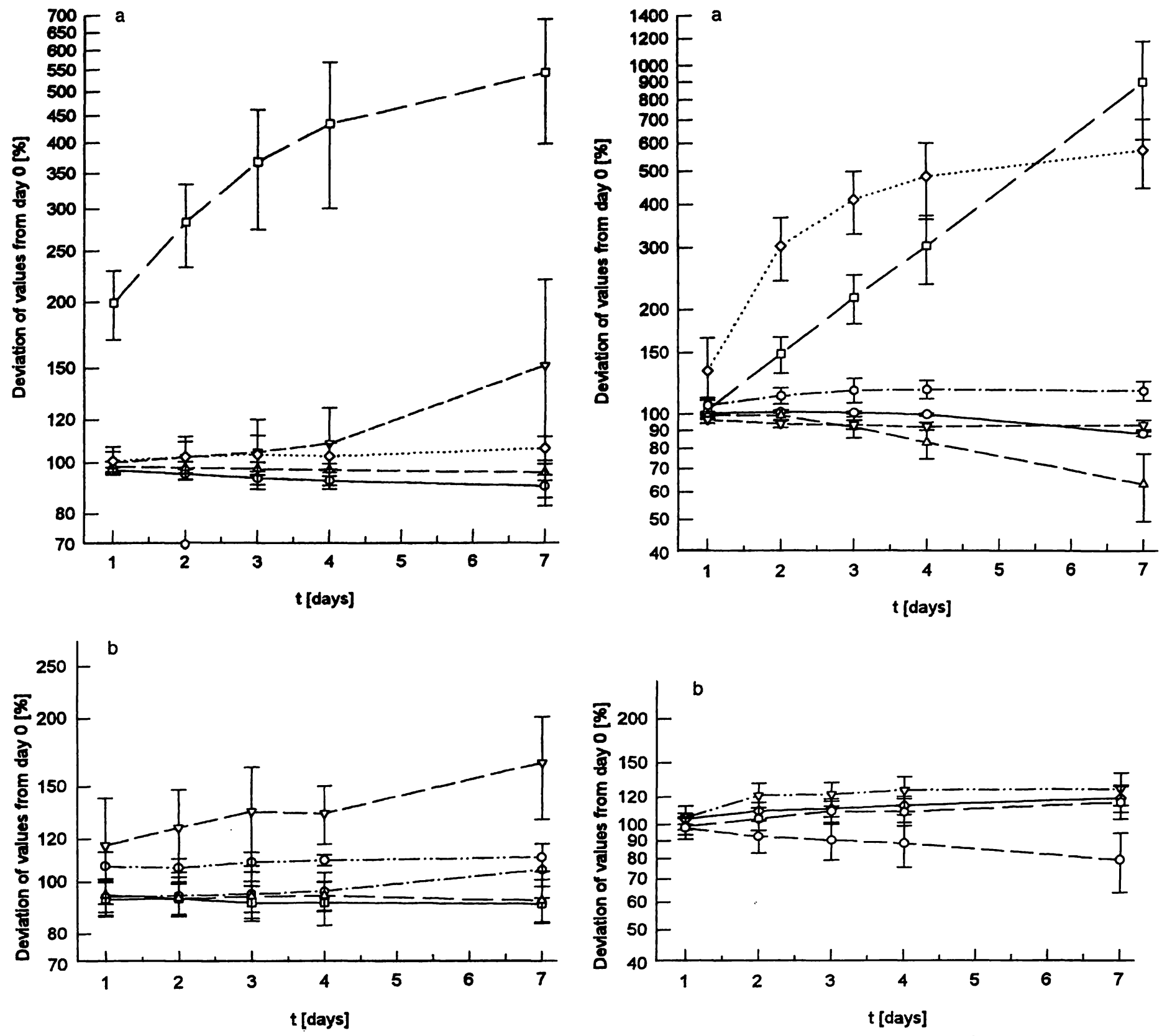

Fig. 4 Storage of not centrifuged vacutainer ${ }^{\circledR}$ tubes at $9^{\circ} \mathrm{C}$. Deviation of the measurable quantities as mean and standard deviation in percentage of the initial value.

a) Electrolytes and trace elements from the top to the bottom: potassium (square), inorganic phosphate (wedge), magnesium (rhomb), chloride (triangle) and sodium (circle).

b) Metabolites and enzymes from the top to the bottom: lactate dehydrogenase (wedge), uric acid (circle), creatinine (hexagon), $\alpha$ amylase (triangle) and alkaline phosphatase (square).

pends on the main and the sub-wavelengths at which the measurement is performed. The above-mentioned interactions in the preanalytical phase are difficult to describe, because not all influences can be simulated in model experiments (2).

\section{Electrolytes}

Sodium, calcium and chloride concentrations decrease in whole blood because these low molecular mass substances enter the erythrocytes under the influence of

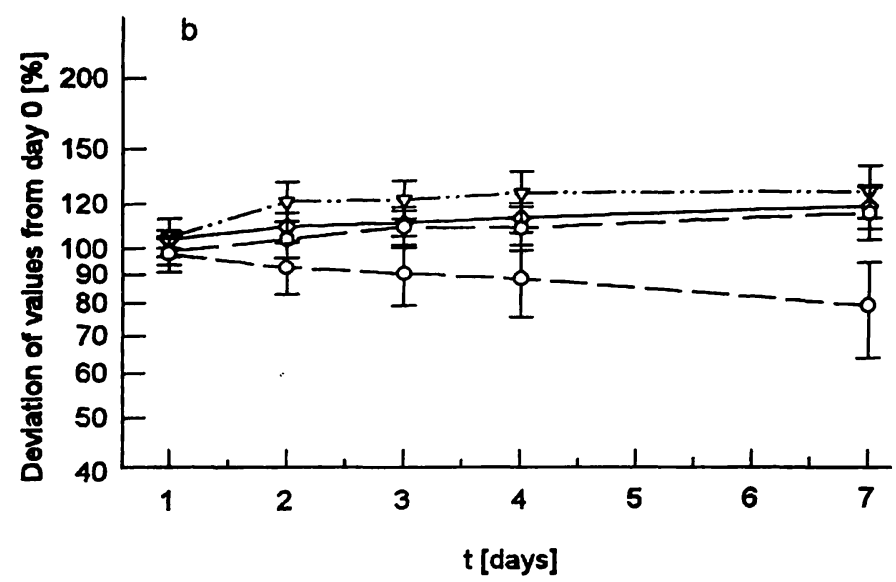

Fig. 5 Storage of not centrifuged vacutainer ${ }^{\circledR}$ tubes at room temperature. Deviation of the measurable quantities as mean and standard deviation in percentage of the initial value.

a) Electrolytes and trace elements from the top to the bottom: potassium (square), inorganic phosphate (rhomb), magnesium (hexagon), chloride (wedge), sodium (circle) and calcium (triangle).

b) Metabolites and lipoproteins from the top to the bottom: creatinine (wedge), urea (rhomb), HDL-cholesterol (hexagon) and LDLcholesterol (circle).

their concentration gradients, namely $19: 1$ for sodium, $128: 1$ for calcium and 1.5: 1 for chloride (8). Additionally, potassium and magnesium ions pass through the erythrocyte membrane due to the serum/erythrocyte ratio of $1: 20$ or $1: 2.5$. The slight increase in potassium after storage of centrifuged tubes is caused by the small number of erythrocytes on the surface of the polyester separation gel. Due to the temperature-dependent activity of the $\mathrm{Na}^{+}-\mathrm{K}^{+}$-ATPase (9), there are fewer shifts of sodium and potassium within the first 4 days, when whole blood is stored at room temperature than when it 
is stored at $9^{\circ} \mathrm{C}$. The phosphatases in serum and whole blood cause a hydrolysis of phosphate esters, leading to an increase in the inorganic phosphate concentration. Since erythrocytes have an essentially higher concentration of phosphate esters, there is a greater increase in whole blood than in serum $(10,11)$.

\section{Metabolites}

No clinically relevant instability was observed in creatinine in serum over a period of one week. When whole blood was stored at room temperature, however, there was an increase in the measured concentrations of this analyte as a result of the non-specific formation of reactants, the so-called pseudocreatinines (12), for example, pyruvate from erythrocyte metabolism (13). Storage of whole blood at $9^{\circ} \mathrm{C}$ had a slight adverse effect on the creatinine concentration indicating that this non-specific interference is influenced by temperature.

Urea in serum was found to be stable for one week. In the uncentrifuged tubes, cleavage of ammonia from basic amino acids may cause a slight interference with respect to the urease/glutamate dehydrogenase reaction. As a result, an apparent continuous increase in urea concentration in whole blood was observed at room temperature.

A small continuous increase in uric acid was observed in serum. In whole blood, haemoglobin may interfere in the measurement of this analyte, since haemoglobin interferes directly with the peridochrom method by spectral interference at $570 \mathrm{~nm}$. In contrast, Keller (3) found a decrease in uric acid in plasma and whole blood, and Sonntag (2) reported a negative interference by haemolysis.

The instability of bilirubin in serum is caused by photooxidation. Additionally, in whole blood, the dichlorophenyl diazonium method (15) (a modified Evelyn-Malloy method) showed a positive interference by haemoglobin, in contrast to the Jendrassik Grof method as reported by other authors $(1-3,16)$. Thus the decrease was compensated by the release of haemoglobin and there was no significant increase in the values.

\section{Lipids}

In serum, cholesterol, as well as HDL- and LDL-cholesterol concentrations, showed no significant shift during storage in the refrigerator over a period of 7 days. Other authors obtained the same results using polyethylene glycol 6000 as precipitating agent (17). In contrast, Khan \& Elkeles (18) observed a decrease in the HDLcholesterol concentration, using heparin manganese/ dextran sulphate for precipitation. Storage of serum at room temperature produced adverse changes, i.e. an increase in the HDL- and a decrease in the LDL-cholesterol concentration, because of incomplete precipitation of LDL- and VLDL-lipoproteins $(19,20)$. The significant rise in cholesterol and HDL-cholesterol (and the decrease in LDL-cholesterol, which is partially compensated in whole blood but not in serum) in whole blood at room temperature resulted from an increase in cholesteryl esters accompanied by a smaller decrease in free cholesterol. This change seems to be a lecithin-cholesterol acyltransferase-dependent (EC 2.3.1.43) cholesterol transport out of blood cells (21). A significant drift in the triacylglycerol concentration was observed at room temperature. This apparent increase could be caused by cleavage of glycerol from phospholipids.

\section{Enzymes}

Inactivation of creatine kinase in serum increases with temperature and bright sunlight. This effect is not reversed by addition of sulphydryl (thiol) compounds. Oxidation of the sulphydryl groups in the active centre, which also causes an inactivation of the enzyme, is reversible. In an optimised assay, containing EDTA to reverse creatine kinase inhibition by calcium ions, and $\mathrm{N}$ acetylcysteine to reactivate the sulphydryl groups, creatine kinase is reactivated by $97 \%$ (22) or to $99 \%$ (23). Thus, in contrast to earlier studies, reactivation of the creatine kinase activity by prior addition of thiol reagents to the sample is not necessary, but in the absence of such an addition we observed a greater decrease in enzyme activity with storage (24).

In whole blood, interference of adenylate kinase released by haemolysis of erythrocytes is inhibited by including diadenosine pentaphosphate and adenosine monophosphate in the reagent. We determined only a moderate temperature-dependent compensation of creatine kinase inactivation caused by other intermediates and enzymes from the erythrocytes, compared with methods using no inhibitor (25). In spite of the inhibitors added in the optimised assay, a high amount of adenylate kinase can also cause an increase in the catalytic concentration of creatine kinase (26).

In serum, a temperature-dependent decrease of aspartate aminotransferase was observed. At $9{ }^{\circ} \mathrm{C}$, the enzyme was stable over 7 days. At room temperature, a slight continuous loss of activity occurred. Similar results have been described by Cuccherini (27) with a smaller decline in activity at lower temperatures. Samples with abnormal values showed a greater decrease. Schmidt (24) has. also described a higher temperature-dependent decrease during storage. In whole blood, the measured aspartate aminotransferase activities did not increase 
significantly over a period of 7 days. The increase was higher at $9{ }^{\circ} \mathrm{C}$ than at room temperature. This was obviously due to the greater stability of the enzyme. A nonsignificant increase due to haemolysis has been described by Yïcel et al. (28). In model experiments other authors have observed a greater increase, due to haemolysis and 40-fold higher activity of aspartate aminotransferase in erythrocytes compared with serum $(2,25)$.

The alanine aminotransferase stability observed in serum corresponds to the data provided by Williams et al. (29), but the decrease at $9^{\circ} \mathrm{C}$ and at room temperature was not significant over a period of 7 days. As far as whole blood is concerned, our results agree with the data confirmed by Ruby et al. (30), who found a greater loss of activity at room temperature than at $4^{\circ} \mathrm{C}$, but in our study the latter had no statistical significance. Cuccherini (27) has shown that the loss of activity in pathological samples is higher than in samples with a normal alanine aminotransferase activity.

Only the measurements of $\gamma$-glutamyltransferase after storage of whole blood at room temperature showed any significant alteration in enzyme activity. The distinct rise in haemolysis causes the release of glutathione, which inhibits enzyme activity at day 7 (31). Persjin \& van der Slik (32) found interference by relatively high haemoglobin concentrations in this method.

Alkaline phosphatase showed a significant decrease after storage in whole blood. $\alpha$-Amylase is stable in serum for one week, while in whole blood, the activity strongly decreased after 7 days at room temperature. The binding of $p$-nitrophenol to haemoglobin is highly dependent on the $\mathrm{pH}$ value of the test system. Therefore, the determination of enzyme activity based on the release of this substance is especially prone to interference at high $\mathrm{pH}$ values. This may explain a more marked decrease in the measured catalytic concentrations of alkaline phosphatase compared with that of $\alpha$-amylase (2).

\section{References}

1. Guder W, Wisser H. Verhalten von Blutbestandteilen während des Transportes (Versand) und der Lagerung von Untersuchungsgut. Mitt Dt Ges f Klin Chemie 1990; 21:4-13.

2. Sonntag $O$. Haemolysis as an interference factor in clinical chemistry. J Clin Chem Clin Biochem 1986; 24:127-39.

3. Keller $\mathrm{H}$. Lagerungsbedingte Fehler bei der Bestimmung von 11 Parametern in heparinisiertem Vollblut. Z Klin Chem Klin Biochem 1975; 13:217-24.

4. Laessing RH, Indriksons AA, Hassemer DJ, Paskey TA, Schwartz TH. Changes in serum chemical values as a result of prolonged contact with the clot. Am J Clin Pathol 1976; 66:598-604.

5. Ono $T$, Kitaguchi $K$, Takehara $M$, Shiiba $M$, Hayami $K$. Serum-constituents analyses: Effect of duration and temperature of storage blood. Clin Chem 1981; 27:35-8.
The slight but significant decrease in lactate dehydrogenase activity in serum at $9^{\circ} \mathrm{C}$ is caused by an instability of the isoforms lactate dehydrogenase 3 , lactate dehydrogenase 4 and lactate dehydrogenase 5 in the cold state (33). At room temperature, no significant change could be detected. In whole blood, a rapid increase in activity was observed because lactate dehydrogenase activity is 260 times higher in erythrocytes than in serum (34).

There were no clinically relevant differences in cholinesterase activity, either in serum over a period of 7 days or in whole blood over 4 days. Similar results were obtained by Balland et al. (35).

\section{Conclusions}

Our study confirmed that blood samples should generally be centrifuged as soon as possible. All measurable quantities examined were stable for four days in separated serum at $9{ }^{\circ} \mathrm{C}$; however, values of inorganic phosphate, uric acid, bilirubin, triacylglycerols, HDL- and LDL-cholesterol and creatine kinase were not sufficiently stable when serum was stored at room temperature. If centrifugation is not possible within $24 \mathrm{~h}$, chloride, inorganic phosphate, magnesium and $\gamma$-glutamyltransferase exceed the limits of stability when the samples are stored at room temperature. At $9{ }^{\circ} \mathrm{C}$ the latter are stable, but sodium, creatinine and alkaline phosphatase exceed the limits.

For the determination of potassium or lactate dehydrogenase in serum the storage of whole blood samples seems not to be acceptable.

\section{Acknowledgement}

We wish to thank the Technical Assistants in our department for their skilful help and Mrs. Joyce Hopper for correction of the manuscript for grammar and style.
6. Harboe M. A method for determination of hemoglobin in plasma by near-ultraviolet spectrophotometry. Scand J Clin Lab Invest 1959; 11:66-70.

7. Richtlinien der Bundesärztekammer. Qualitätsicherung der quantitativen Bestimmungen im Laboratorium. Dt Ärztebl 1988; 11:697-712.

8. Wissenschaftliche Tabellen Geigy: Teilband Körperflüssigkeit. Basel: Ciba Geigy, 1979:82.

9. Harth $O$. Wasserhaushalt, Stoff- und Flüssigkeitstransport. In: Schmidt RF, Thews G, editors. Physiologie des Menschen. Berlin: Springer Verlag, 1980. 717-8.

10. Henry RJ, Cannon DC, Winkelmann JW. Phosphate. In: Henry' RJ, Cannon DC, Winkelmann JW, editors. Clinical chemistry, principles and technics. 2nd edition New York: Harper and Row, Publishers; 1974:720-8. 
11. Richterich R. Colombo JP, editors. Klinische Chemie - Theorie, Praxis, Intcrpretation, 4. Auflage Basel: Karger Verlag, 1978:403-11.

12. Keller H. Klinisch-chemische Labordiagnostik für die Praxis. 2. Auflage Stuttgart: Thieme Verlag, 1991:223.

13. Henninger G, Bergmeyer HU. Specimens and samples in food chemistry, cosmetics, pharmacy. In: Bergmeyer HU, editor. Methods of enzymatic analysis, Vol. 2. Weinheim: Verlag Chemie, 1983:2-20.

14. Rehak NN, Chiang BT. Storage of whole blood: effect of temperature on the measured concentrations of analytes in serum. Clin Chem 1988; 34:2111-4.

15. Wahlefeld AW, Herz G, Bernt E. Modification of the MalloyEvelyn-method for a simple determination of total bilirubin in serum. Scand J Clin Lab Invest 1972; 29 Suppl 126: abstract 11.12 .

16. Balisteri WF, Rei R. Methods for the determination of bilirubin. In: Burtis CA, Ashwood ER, editors. Tietz textbook of clinical chemistry. 2nd edition Philadelphia: Saunders, 1994:1463-9.

17. Jung K, Blank W, Scholz D. Stability of subfractions of highdensity lipoproteins in stored sera. Clin Chem 1986; 32:1986.

18. Khan SR, Elkeles RS. Effect of storage on the precipitation procedure for the measurement of HDL subclasses in serum. Clin Chim Acta 1984; 144:59-63.

19. Bachorik PS. Walker R, Brownell KD, Stunkard AJ, Kwiterovich PO. Determination of high density lipoprotein-cholesterol in stored human plasma. J Lipid Res 1980; 21:608-16.

20. Hankinson SE, London SJ, Chute CG, Barbieri RL, Jones L, Kaplan LA et al. Effect of transport on the stability of biochemical markers in blood. Clin Chem 1989; 35:2313-6.

21. Rühling K, Lang A, Holtz H, Winkler L, Schlag B, Till U. Increase in plasma total and lipoprotein cholesterol during incubation of whole blood samples at $37^{\circ} \mathrm{C}$. Clin Chim Acta 1992; 205:205-12.

22. Helger R. Methods for the determination of creatine kinase activity. In: Lang $\mathrm{H}$, editor. Creatine kinase isoenzymes. Berlin: Springer Verlag, 1981:31-40.

23. Moss DW, Henderson AR. Creatine kinase. In: Burtis CA, Ashwood ER, editors. Tietz textbook of clinical chemistry 2 nd edition. Philadelphia: Saunders, 1984:797-809.
24. Schmidt E, Schmidt FW, editors. Kleine Enzym-Fibel, 3rd edition. Mannheim: Boehringer Mannheim GmbH, 1981.

25. Frank JJ, Bermes EW, Bickel MJ, Watkins BF. Effect of in vitro hemolysis on chemical values for serum. Clin Chem 1978; 24:1966-70.

26. Stein W. Creatin-Kinase (CK), Creatin-Kinase (MB). In: Thomas L, editor. Labor und Diagnose, 4th edition. Marburg: Die Medizinische Verlagsgesellschaft, 1992:89-106.

27. Cuccherini B, Nussbaim SJ, Seeff LB, Lukacs L, Zimmermann HJ. Stability of aspartate aminotransferase and alanine aminotransferase activities. J Lab Clin Med 1983; 102:370-6.

28. Yücel $\mathrm{D}$, Dalva $\mathrm{K}$. Effect of in vitro hemolysis on 25 common biochemical tests. Clin Chem 1992; 38:575-7.

29. Williams KM, Williams AE, Kline LM, Dodd RY. Stability of serum alanine aminotransferase activity. Transfusion 1987; $27: 431-3$.

30. Ruby SG, Nicholas ER, Lonser RE. Pre-analytical variation in alanine aminotransferase. Clin Chem 1988; 34:744-5.

31. Gressner AM. Leber und Gallenwege. In: Greiling H, Gressner AM, editors. Lehrbuch der Klinischen Chemie und Pathobiochemie. Stuttgart: Schattauer Verlag, 1989:421-543.

32. Persijn JP, van der Slik W. A new method for the determination of $\gamma$-glutamyltransferase in serum. J Clin Chem Clin Biochem $1976 ; 14: 421-7$.

33. Jacobs E, Hissin PJ, Propper W, Mayer L, Sarkozi L. Stability of lactate dehydrogenase at different storage temperatures. Clin Biochem 1986; 19:183-8.

34. Wisser $H$. Einflußgrößen und Störfaktoren. In: Greiling $H$, Gressner AM, editors. Lehrbuch der Klinischen Chemie und Pathobiochemie. Stuttgart: Schattauer Verlag, 1989:38-57.

35. Balland M, Vincent-Viry M, Henny J. Effect of long-term storage on human plasma cholinesterase activity. Clin Chim Acta 1992; 211:129-31.

Dr. med. Michael Heins Institut für Klinische Chemie und Laboratoriumsdiagnostik Heinrich-Heine-Universität Düsseldorf Moorenstraße 5 D-40001 Düsseldorf Germany 